\title{
Türkçe öğretmeni adaylarının eleştirel okuma öz yeterlik algıları ile okuma motivasyonları arasındaki ilişkinin incelenmesi
}

\section{Nurullah ŞAHİN ${ }^{1}$}

APA: Şahin, N. (2019). Türkçe öğretmeni adaylarının eleştirel okuma öz yeterlik algıları ile okuma motivasyonları arasındaki ilişkinin incelenmesi. RumeliDE Dil ve Edebiyat Araștırmaları Dergisi, (16), 214-233. DOI: 10.29000/rumelide.618195

$\ddot{\mathbf{O} z}$

Bu araştırmanın amacı; Türkçe öğretmeni adaylarının eleştirel okuma öz yeterlik algıları ile okuma motivasyonlarını çeşitli değişkenler açısından incelemek ve Türkçe öğretmeni adaylarının eleştirel okuma öz yeterlik algıları ile okuma motivasyonları arasındaki ilişkiyi tespit etmektir. Çalışmada nicel araştırma yaklaşımı benimsenmiş olup ilişkisel tarama modeli kullanılmıştır. Araştırmanın çalışma grubunu 2018-2019 eğitim öğretim yılı güz dönemi içerisinde Amasya Üniversitesi Eğitim Fakültesi Türkçe Eğitimi Ana Bilim Dalında öğrenim görmekte olan toplam 206 Türkçe öğretmeni adayı oluşturmaktadır. Araştırmada veri toplama aracı olarak Karabay (2013) tarafından geliştirilen "Eleştirel Okuma Öz Yeterlik Algı Ölçeği” ile Schutte ve Malouff (2007) tarafından geliştirilen ve Yıldız vd. (2013) tarafından Türkçeye uyarlanan "Yetişkin Okuma Motivasyonu Ölçeği" kullanılmıştır. Araştırmadan elde edilen tüm veriler SPSS 25 paket programında parametrik testler kullanılarak analiz edilmiştir. Çalışmada; Türkçe öğretmeni adaylarının eleştirel okuma öz yeterlik algılarının cinsiyet, kendine ait kitaplığının olup olmaması ve yılda okuduğu kitap sayısı değişkenlerine göre anlamlı olarak farklılaştığı; öğrenim görülen sınıf düzeyi değişkenine göre ise, anlamlı olarak farklılaşmadığı görülmüştür. Türkçe öğretmeni adaylarının okuma motivasyonlarının ise cinsiyet, sınıf ve yılda okunan kitap sayısı değişkenlerine göre anlamlı bir şekilde farklılaştı̆̆ı; kendine ait kitaplığının olup olmaması değişkenine göre ise anlamlı olarak farklılaşmadı̆̆ı tespit edilmiştir. Ayrıca Türkçe öğretmeni adaylarının eleştirel okuma öz yeterlik algıları ile okuma motivasyonları arasında pozitif yönde ve orta düzeyde bir ilişki olduğu görülmüştür.

Anahtar kelimeler: Eleştirel okuma öz yeterlik algısı, okuma motivasyonu, Türkçe öğretmeni adayları.

\section{An analysis of the correlation between critical reading self-sufficiency perceptions and reading motivations of Turkish teacher candidates}

\begin{abstract}
This research is aimed at making a multi-variable analysis of critical reading self-sufficiency perceptions and reading motivations of Turkish teacher candidates and identifying the correlation between critical reading self-sufficiency perceptions and reading motivations of Turkish teacher candidates. The study is based on quantitative research method using correlational survey model. The study group consists of 206 students studying at the Turkish Education Department of the Faculty of Education of Amasya University in the fall semester of 2018-2019 academic year. The data collection tool used in the research was the "Critical Reading Self-Sufficiency Perception Scale" developed by Karabay (2013) and the "Adult Reading Motivation Scale" developed by Schutte and

$1 \quad$ Dr. Öğr. Üyesi, Ağrı İbrahim Ceçen Üniversitesi, Eğitim Fakültesi, Türkçe ve Sosyal Bilimler Eğitimi, Türkçe Dili Eğitimi ABD (Ağrı, Türkiye), nsahin.86@gmail.com, ORCID ID: 0000-0002-3462-0369 [Makale kayıt tarihi: 16.07.2019-kabul tarihi: 20.09.2019; DOI: 10.29000/rumelide.618195]




\begin{abstract}
Malouff (2007) and adapted to Turkish by Yildiz et al. (2013). All data obtained from the survey were analyzed in SPSS 25 package program using parametric tests. The study demonstrated that the critical reading self-sufficiency perceptions of Turkish teacher candidates differed significantly based on variables such as sex, having a personal library or not and the number of books read in a year; but did not differ significantly based on the variable of educational grade. On the other hand, it was determined that reading motivation of Turkish teacher candidates differed significantly based on variables such as sex, class and the number of books read in a year; but did not differ significantly based on the variable of having a personal library. It was also seen that there was a positive and moderate correlation between critical reading self-sufficiency perceptions and reading motivations of Turkish teacher candidates.
\end{abstract}

Keywords: Critical reading self-sufficiency perceptions, reading motivation, Turkish teacher candidates.

\title{
Giriş
}

Dört temel dil becerisinden biri olan ve dilin anlama boyutu içerisinde kullanılan okuma becerisi; çağdaş insanın bilgiye ulaşmada kullandığı önemli yollardan biridir. Günümüzde insanlar, bilgiye ulaşmak için çok farklı kaynaklar kullanmaktadırlar. Okuma; bu yollardan biri olmakla birlikte insanın bireysel, sosyal, zihinsel, dilsel, toplumsal vb. birçok gelişimine de katkı sağlar. Okuma "bir yazıyı, sözcükleri, cümleleri noktalama işaretleri ve öteki ögeleriyle görmek, algılamak, tanımak ve bunların anlamını kavramak, kıyaslamalar yapmak, yorumlamak, fikir yürütmek, yargıya varmak ve olayları analiz ederek, sentez yaparak değerlendirmektir" (Güngör, 2005, s. 101). Basılı harfleri seslendirmenin çok ötesinde bir etkinlik olan okuma, karmaşık zihinsel süreçleri ve üst düzey düşünme becerilerini de gerektiren bir beceridir. Okuma da esas olan, metnin anlatmak istediği mesaja eksiksiz ulaşmak ve metnin tamamına hâkim olmaktır.

Okuma becerisi insanın doğuştan getirdiği bir beceri değildir. "Dil edinimi okul öncesinde çocuğun ailesi ve yakın çevresiyle etkileşimi sonucunda başlar. Ancak dilin doğru ve etkili kullanımıyla okuma ve yazma becerilerinin gelişimi okulda veya başka bir eğitim öğretim kurumunda sistemli bir çalışmayı gerektirebilir." (Alyılmaz, 2010, s. 729). Sağlıklı ve etkili bir okuma becerisini kazanmanın yollarından biri de, okullardaki eğitim öğretim faaliyetleridir. Okullarda verilen okuma eğitimi, çocuklara okumayı öğretmenin yanı sıra onları iyi birer okur olarak yetiştirmek ve onlara okuma sevgisi aşılamak bağlamında da son derece önemlidir. Çünkü okuma sevgisi kazanmış ve iyi bir okur olabilmiş bireyler ancak okumayı alışkanlık getirebilir ve hayatlarının her anında okumayı ve bilgiyi ön plana çıkarabilir. Bu konuda, başta öğretmenler olmak üzere eğitim öğretim sürecinin tüm paydaşlarına önemli ve kritik görevler düşmektedir. Ayrıca iyi bir okuma eğitimi, çocukların akademik başarıları açısından da önemlidir. Tüm derslerin belli bir oranda okuduğunu anlama becerisi gerektirmesinden dolayı okuma becerisi istenilen düzeyde olmayan öğrencinin derslerinde başarılı olması da düşünülemez.

Okuma becerisini geliştirmek için birçok yöntem ve teknikten bahsedilebilir. Bunlardan biri de eleştirel okumadır. "Bireyin okuduklarını yargılaması, sorgulaması, değerlendirmesi, güvenilir kaynaklardan yararlanarak ve kendi aklını kullanarak bir sonuca varması" (Özensoy, 2012, s. 198) şeklinde tanımlanabilen eleştirel okuma; öğrenciye sorgulamayı, muhakeme ve kıyaslama yapmayı öğretme amacı taşıdığından diğer yöntem ve tekniklerin de birkaçını kapsamaktadır. Eleştirel okumada, üst düzey düşünme becerileri ve karmaşı zihinsel süreçler ön plana çımaktadır. Çünkü eleştirel okuma; okuduklarını peşinen kabullenme yerine sorgulama, araştırma, karşılaştırma, ilişkilendirme, 
An analysis of the correlation between critical reading self-sufficiency perceptions and reading motivations of Turkish teacher candidates / N. Şahin (p. 214-233)

yorumlama, seçme, hükme varma gibi temeller üzerine kurulu bir okuma eylemidir. Günümüz dünyasında okuma materyallerinin çok fazla olduğu düşünülünce, bireylerin ve öğrencilerin doğru okuma materyaline ve en önemlisi de doğru bilgiye ulaşabilmesi bağlamında, eleştirel okuma kritik öneme sahiptir.

Eleştirel okumanın temelinde yer alan üst düzey düşünme becerileri, aynı zamanda yapılandırmacı eğitim anlayışının da temel prensiplerini oluşturmaktadır. Yapılandırmacı eğitim anlayışında, öğrencilerin bu beceriler bağlamında yetiştirilmesi ve doğru bilgiye bu beceriler aracılığıyla öğrencinin kendisinin ulaşması önemli görülmektedir. Bu nedenle öğrencilerin eleştirel okuma bağlamında yetkin ve öz yeterlik algılarının yüksek olması yapılandırmacı anlayışın ortaya koymak istediği ideal öğrenci profilinin özelliklerindendir.

Öz yeterlik kavramı, bireylerin karşılaştıkları durumlarla başa çıkma ve belli bir konuya ilişkin başarılı olma yetkinliğine yönelik kendi algılarını (Senemoğlu, 2011) ifade etmektedir. "Özyeterlik algısı gerçek yeterlik düzeyinden çok, yeterlik düzeyi hakkındaki inançla ilgilidir” (Kurbanoğlu, 2004, s. 139). Öz yeterlik algısı, davranışların oluşmasında ve gerekli olan davranışı sürdürebilme noktasında önemli bir etkendir (Bandura, 1997). Nitekim öz yeterlik algısı yüksek bireyler, öz yeterlik algısı düşük olan bireylere göre; karşılaştıkları durumun üstesinden gelebilmek adına daha çok motive olurlar ve bu uğurda daha çok mücadele ederler. Yani öz yeterlik ne kadar yüksek olursa bireydeki sabır, mücadele gücü ve kendine güven duygusu da o kadar yüksek olur (Senemoğlu, 2011; Saracaloğlu, Yenice, Karasakaloğlu ve Gencel, 2008 ve Bıkmaz, 2002). Bunlardan hareketle bireyin eleştirel okuma bağlamında kendi kapasitesine olan inancı ifade eden eleştirel okuma öz yeterlik algısı, eleştirel okumanın başarıya ulaşması açısından önemlidir. Yani eleştirel okuma öz yeterlik algısı, okumanın amacına ulaşmasını etkileyen duyuşsal bir faktördür ve bu noktada okuma başarısını etkileyen diğer duyuşsal faktörlerle de yakından ilişkilidir. Eleştirel okuma öz yeterlik algısının ilişki olduğu duyuşsal faktörlerden biri de okuma motivasyonudur. Öz yeterlik inancının, motivasyonu yükseltici, performansı liartırıcı etkisi açıktır (Işık, 2001).

Motivasyon kavramı, genel manada kişinin amacı için harekete geçmesini ve eylemlerinde kararlı olmasını sağlayan dürtü, istek veya hırs olarak tanımlanabilir (Slavin, 2013; Selçuk, 2007; Katrancı, 2015). Bu bağlamda, okuma motivasyonu ise, "Okuma süreçlerini, sonuçlarını ve konularını etkileyen kişisel amaçlar, değerler ve inançlar" (Guthrie ve Wigfield, 2000, s. 405) şeklinde tanımlanmaktadır. Başka bir ifadeyle okuma motivasyonu, "kitabı okumaya yönelik istek, merak, ilgi, tutum ve davranışın oluşabilmesi; kitap okumanın değerli bir eylem olarak görülmesi ve kitap okuma alışkanlığının devam edebilmesi için gerekli olan güç" (Katrancı, 2015, s. 50) olarak tanımlanmıştır.

Motivasyon, okumada temel bir rol oynamakta ve okuma başarısını doğrudan etkilemektedir. Okuma motivasyonu yüksek olan öğrencilerin okuma başarıları ve okuma alışkanlıkları da yüksektir (Guthrie, 2004; Baker, 2003; Kuşdemir, 2014). Bu sebeple; öğrencilerin okuma motivasyonlarını artırıcı tedbirler almak ve bu bağlamda gerekli düzenlemeleri yapmak önemli görülmektedir.

Bireylerin okumaya yönelik isteklerini, ilgilerini artıran ve onların okumak için harekete geçmelerini sağlayan okuma motivasyonu; bütün yaş gruplarında önem arz etmesine rağmen, okuryazar bireyler yetiştirebilme adına, küçük yaş gruplarında çok daha fazla önemli görülmektedir (Öztürk ve İleri Aydemir, 2013). 
Eleştirel okuma öz yeterlik algısı ve okuma motivasyonu, bireylerin okuma başarılarını doğrudan etkileyen iki önemli duyuşsal etkendir. Bu iki faktör arasında yakından bir ilişki olduğu da açıtır. Alanyazın incelendiğinde, Türkçe öğretmeni adaylarının eleştirel okuma öz yeterlik algıları ile okuma motivasyonlarını inceleyen ve bu iki faktör arasındaki ilişkiyi araştıran bir çalışmaya rastlanılmamıştır. $\mathrm{Bu}$ nedenle bu çalışmadan elde edilen sonuçların, bundan sonraki çalışmalara yol göstereceği düşünülmektedir.

\section{Araştırmanın amacı}

$\mathrm{Bu}$ çalışmada, Türkçe öğretmeni adaylarının eleştirel okuma öz yeterlik algılarının ve okuma motivasyonlarının çeşitli değişkenler açısından incelenmesi ve eleştirel okuma öz yeterlik algıları ile okuma motivasyonları arasındaki ilişkinin tespit edilmesi amaçlanmıştır. Bu amaç doğrultusunda çalışmanın alt problemleri aşă̆ıdaki şekilde belirlenmiştir:

1. Türkçe öğretmeni adaylarının eleştirel okuma öz yeterlik algıları ve okuma motivasyonları cinsiyetlerine göre anlamlı bir şekilde farklılaşmakta mıdır?

2. Türkçe öğretmeni adaylarının eleştirel okuma öz yeterlik algıları ve okuma motivasyonları öğrenim gördükleri sınıf düzeyine göre anlamlı bir şekilde farklılaşmakta mıdır?

3. Türkçe öğretmeni adaylarının eleştirel okuma öz yeterlik algıları ve okuma motivasyonları aile gelir düzeylerine göre anlamlı bir şekilde farklılaşmakta mıdır?

4. Türkçe öğretmeni adaylarının eleştirel okuma öz yeterlik algıları ve okuma motivasyonları kendilerine ait kitaplıklarının olup olmamasına göre anlamlı bir şekilde farklılaşmakta mıdır?

5. Türkçe öğretmeni adaylarının eleştirel okuma öz yeterlik algıları ve okuma motivasyonları yılda okudukları kitap sayısına göre anlamlı bir şekilde farklılaşmakta mıdır?

6. Türkçe öğretmeni adaylarının eleştirel okuma öz yeterlik algıları ve okuma motivasyonları anne veya babalarının kitap okuyup okumamalarına göre anlamlı bir şekilde farklılaşmakta mıdır?

7. Türkçe öğretmeni adaylarının eleştirel okuma öz yeterlik algıları ile okuma motivasyonları arasında nasıl bir ilişki vardır?

\section{Yöntem}

\section{Araştırma modeli}

Çalışmada, ilişkisel tarama modeli kullanılmıştır. İlişkisel tarama modeli, ilişkileri ve bağlantıları inceleyen, iki veya daha fazla grup arasında bir ilişkinin olup olmadığını tespit etmek amacıyla kullanılan bir araştırma modelidir (Büyüköztürk vd., 2011; Karasar, 2008; Mcmillan ve Schumaer, 2010).

\section{Çalışma grubu}

Araştırmanın çalışma grubunu, 2018-2019 eğitim öğretim yılı güz dönemi içerisinde Amasya Üniversitesi Eğitim Fakültesi Türkçe Eğitimi Ana Bilim Dalında öğrenim görmekte olan toplam 206 Türkçe öğretmeni adayı oluşturmaktadır. Öğretmen adaylarının kişisel özelliklerine ilişkin bilgiler Tablo 1'de verilmiştir. 
An analysis of the correlation between critical reading self-sufficiency perceptions and reading motivations of Turkish teacher candidates / N. Şahin (p. 214-233)

Tablo 1. Çalışma Grubunun Kişisel Özelliklerine İlişkin Bilgiler

\begin{tabular}{|c|c|c|c|c|}
\hline & & $\mathbf{N}$ & $\%$ & Toplam \\
\hline \multirow[t]{2}{*}{ Cinsiyet } & Kadın & 113 & 54,9 & \multirow{2}{*}{$\begin{array}{l}206 \\
(\% 100)\end{array}$} \\
\hline & Erkek & 93 & 45,1 & \\
\hline \multirow[t]{4}{*}{ Sinıf } & 1. Sinif & 42 & 20,4 & \multirow{4}{*}{$\begin{array}{l}206 \\
(\% 100)\end{array}$} \\
\hline & 2. Sinif & 60 & 29,1 & \\
\hline & 3. Sinif & 52 & 25,2 & \\
\hline & 4. Sinif & 52 & 25,2 & \\
\hline \multirow{4}{*}{$\begin{array}{l}\text { Ailenizin aylık gelir düzeyi ortalama } \\
\text { ne kadardır? }\end{array}$} & $1-2000 \mathrm{TL}$ & 91 & 44,2 & \multirow{4}{*}{$\begin{array}{l}206 \\
(\% 100)\end{array}$} \\
\hline & $2001-4000 \mathrm{TL}$ & 90 & 43,7 & \\
\hline & 4001-6000 TL & 15 & 7,3 & \\
\hline & 6000 Üzeri & 10 & 4,9 & \\
\hline \multirow{2}{*}{$\begin{array}{l}\text { Kendinize ait bir kitaplığınız var } \\
\text { mı? }\end{array}$} & Var & 118 & 57,3 & \multirow{2}{*}{$\begin{array}{l}206 \\
(\% 100)\end{array}$} \\
\hline & Yok & 88 & 42,7 & \\
\hline \multirow{5}{*}{$\begin{array}{l}\text { Yilda ortalama kaç kitap } \\
\text { okuyorsunuz? }\end{array}$} & Hiç & 5 & 2,4 & \multirow{5}{*}{$\begin{array}{l}206 \\
(\% 100)\end{array}$} \\
\hline & 1-3 Adet & 32 & 15,5 & \\
\hline & 4-7 Adet & 65 & 31,6 & \\
\hline & 8-10 Adet & 46 & 22,3 & \\
\hline & 10 Üzeri & 58 & 28,2 & \\
\hline \multirow{2}{*}{$\begin{array}{l}\text { Anne ve babanizdan en az birisi } \\
\text { kitap okuyor mu? }\end{array}$} & Evet & 185 & 89,8 & \multirow{2}{*}{$\begin{array}{l}206 \\
(\% 100)\end{array}$} \\
\hline & Hayır & 21 & 10,2 & \\
\hline
\end{tabular}

\section{Veri toplama araçları}

Araştırmada iki adet veri toplama aracı kullanılmıştır. Bunlar;

Eleştirel Okuma Öz Yeterlik Algı Ölçeği: Araştırmada Türkçe öğretmeni adaylarının eleştirel okuma öz yeterlik algılarını tespit edebilmek için Karabay (2013) tarafından geliştirilen "Eleştirel Okuma Öz Yeterlik Algı Ölçeği” kullanılmıştır. Ölçek 5’li likert tarzında hazırlanmış, 41 madde ve 3 alt boyuttan oluşan bir ölçektir. Ölçeğin alt boyutlarına ilişkin elde edilen iç güvenlik katsayılarına bakıldığında;

Değerlendirme alt boyutunun iç güvenirlik katsayısı .91,

Araştırma / İnceleme alt boyutunun iç güvenirlik katsayısı .78 ve

Görsel alt boyutunun iç güvenirlik katsayısı ise, .69 olarak tespit edilirken, ölçeğin bütününe ait iç güvenirlik katsayısı .91 olarak hesaplanmıştır. Güvenirlik ve geçerlik çalışmaları, ölçeğin kullanılabilir özelliklere sahip olduğunu göstermektedir.

Yetişkin Okuma Motivasyonu Ölçeği: Türkçe öğretmeni adaylarının okuma motivasyonlarını tespit edebilmek için Schutte ve Malouff (2007) tarafından geliştirilen ve Yıldız vd. (2013) tarafından Türkçeye uyarlanan "Yetişkin Okuma Motivasyonu Ölçeği” kullanılmıştır. 5’li likert tipinde hazırlanmış 
olan ölçeğin aslı 4 alt boyut ve 21 maddeden oluşurken, Türkçeye uyarlanan versiyonu ise, 4 alt boyut ve 19 madden oluşmaktadır. Ölçeğin alt boyutlarına bakıldı ̆̆ında;

Okuyucu olmanın önemine dair eğilimleri ifade eden "Benlik" alt boyutunun iç güvenirlik katsayısı .82; yeterli bir okuyucu olmaya yönelik eğilimlerin ifade edildiği "Yeterlilik" alt boyutunun iç güvenirlik katsayısı .60; iyi bir okuyucu olarak bilinmeye ve okuma performansının başkaları tarafından bilinmesine yönelik eğilim ifadelerini içeren "Tanınma" alt boyutunun iç güvenirlik katsayısı .78 ve son olarak diğer alanlarda başarılı olabilmek için okumaya yönelik eğilimleri ifade eden "Diğer" alt boyutunun iç güvenirlik katsayısı ise, .72 olarak hesaplanmıştır. Ölçeğin genelinin iç güvenirlik katsayısı ise, .86 olarak tespit edilmiştir. Yapılan hesaplamalar, elde edilen ölçeğin kullanılabilir bir ölçme aracı olduğunu göstermektedir.

\section{Verilerin analizi}

Araştırma için toplanan verilerin normal dağılım gösterip göstermediğini tespit etmek için çarpıklık ve basıklık değerleri incelenmiştir. Elde edilen sonuçlar, verilerin normal dağıldığını gösterdiğinden yapılan analizlerde parametrik testler kullanılmıştır. Bu bağlamda, Türkçe öğretmeni adaylarının eleştirel okuma öz yeterlik algılarının ve okuma motivasyonlarının "cinsiyet", "kendine ait kitaplık bulunup bulunmaması" ve "anne ve babadan en az birinin kitap okuyup okumadığı" değişkenlerine göre anlamlı bir farklılık gösterip göstermediği bağımsız t-testi analizi ile; "sınıf", "aile gelir düzeyi” ve "yılda okunan kitap sayısı” değişkenlerine göre anlamlı bir farklılık gösterip göstermediği ise, tek faktörlü varyans analizi ile incelenmiştir. Tek faktörlü varyans analizi neticesinde anlamlı farkın hangi gruplar lehine olduğunu tespit etmede, Tukey testinden faydalanılmıştır. Türkçe öğretmeni adaylarının eleştirel okuma öz yeterlik algıları ile okuma motivasyonları arasındaki ilişki ise, basit korelasyon analizi tekniği ile incelenmiştir.

\section{Bulgular}

\section{Araştırmadan elde edilen verilerin normallik testi sonuçları}

Analizlere geçmeden önce verilerin normal dağılım gösterip göstermediklerini tespit etmek için çarpıklık ve basıklık değerlerine bakılmıştır. Elde edilen sonuçlar aşağıdaki tabloda gösterilmiştir.

Tablo 2. Araştırma İçin Toplanan Verilerin Çarpıklık ve Basıklık Değerleri

\begin{tabular}{|c|c|c|c|c|}
\hline & \multicolumn{2}{|l|}{$\mathbf{N}$} & \multirow[t]{2}{*}{ Skewness } & \multirow[t]{2}{*}{ Kurtosis } \\
\hline & Valid & Missing & & \\
\hline Eleştirel Okuma Değerlendirme Alt Boyutu & 206 & o &,- 390 &,- 083 \\
\hline Eleştirel Okuma Araştırma / İnceleme Alt Boyutu & 206 & 0 &,- 067 &,- 568 \\
\hline Eleştirel Okuma Görsel Alt Boyutu & 206 & o &,- 079 &,- 148 \\
\hline Motivasyon Ölçeği Benlik Alt Boyutu & 206 & o &,- 092 &,- 285 \\
\hline Motivasyon Ölçeği Yeterlilik Alt Boyutu & 206 & o &,- 055 & ,129 \\
\hline Motivasyon Ölçeği Tanınma Alt Boyutu & 206 & $\mathrm{O}$ &,- 244 &,- 541 \\
\hline Motivasyon Ölçeği Diğer Alt Boyutu & 206 & O &,- 278 &,- 452 \\
\hline
\end{tabular}


An analysis of the correlation between critical reading self-sufficiency perceptions and reading motivations of Turkish teacher candidates / N. Şahin (p. 214-233)

Tablo 2 incelendiğinde araştırma için toplanan verilerin çarpıklık ve basıklık değerlerinin tamamının +1 ile -1 arasında olduğu görülmektedir. Bu durum Hair vd. (2013)'e göre verilerin normal dağıldığını göstermektedir. Bu sebeple de veriler analiz edilirken parametrik testlerden faydalanılmıştır.

Türkçe öğretmeni adaylarının eleştirel okuma öz yeterlik algılarının ve okuma motivasyonlarının cinsiyet değişkenine göre incelenmesi

Bu bölümde; Türkçe öğretmeni adaylarının eleştirel okuma öz yeterlik algılarının ve okuma motivasyonlarının cinsiyete göre anlamlı bir şekilde farklılaşıp farklılaşmadığı araştırılmıştır. Bunun için Türkçe öğretmeni adaylarının ölçeklere vermiş oldukları cevaplar bağımsız örneklem t- testi ile analiz edilmiştir. İlgili analizden elde edilen sonuçlar Tablo 3’te gösterilmiştir.

Tablo 3. Türkçe Öğretmeni Adaylarının Eleştirel Okuma Öz Yeterlik Algılarının ve Okuma Motivasyonlarının Cinsiyete Göre Farklılaşıp Farklılaşmadığına İliş̧kin Analiz Sonuçları

\begin{tabular}{|c|c|c|c|c|c|c|}
\hline & Cinsiyet & $\mathbf{N}$ & $\mathbf{X}^{-}$ & S.S & $\mathbf{t}$ & $\mathbf{p}$ \\
\hline \multirow[t]{2}{*}{ Eleştirel Okuma Değerlendirme Alt Boyutu } & Kadın & 113 & 3,89 &, 527 & \multirow[t]{2}{*}{,121 } & \multirow[t]{2}{*}{,904 } \\
\hline & Erkek & 93 & 3,88 &, 587 & & \\
\hline \multirow{2}{*}{$\begin{array}{l}\text { Eleştirel Okuma Araştırma / Ínceleme Alt } \\
\text { Boyutu }\end{array}$} & Kadın & 113 & 3,79 & 544 & \multirow[t]{2}{*}{,- 097} & \multirow[t]{2}{*}{,923 } \\
\hline & Erkek & 93 & 3,80 & 571 & & \\
\hline \multirow[t]{2}{*}{ Eleştirel Okuma Görsel Alt Boyutu } & Kadın & 113 & 3,27 &, 703 & \multirow[t]{2}{*}{$-2,782$} & \multirow[t]{2}{*}{,006 } \\
\hline & Erkek & 93 & 3,54 & ,692 & & \\
\hline \multirow[t]{2}{*}{ Motivasyon Ölçeği Benlik Alt Boyutu } & Kadın & 113 & 3,97 & ,493 & \multirow[t]{2}{*}{2,318} & \multirow[t]{2}{*}{,021 } \\
\hline & Erkek & 93 & 3,81 &, 512 & & \\
\hline \multirow[t]{2}{*}{ Motivasyon Ölçeği Yeterlilik Alt Boyutu } & Kadın & 113 & 3,54 & ,636 & \multirow[t]{2}{*}{,- 494} & \multirow[t]{2}{*}{,622 } \\
\hline & Erkek & 93 & 3,58 & 603 & & \\
\hline \multirow[t]{2}{*}{ Motivasyon Ölçeği Tanınma Alt Boyutu } & Kadın & 113 & 3,32 & ,980 & \multirow[t]{2}{*}{,431 } & \multirow[t]{2}{*}{,667 } \\
\hline & Erkek & 93 & 3,26 & ,939 & & \\
\hline \multirow[t]{2}{*}{ Motivasyon Ölçeği Diğer Alt Boyutu } & Kadın & 113 & 3,75 & 635 & \multirow[t]{2}{*}{1,179} & \multirow[t]{2}{*}{240} \\
\hline & Erkek & 93 & 3,64 &, 709 & & \\
\hline
\end{tabular}

Tablo 3 incelendiğinde; eleştirel okuma öz yeterlik algı ölçeğinin “Görsel” alt boyutunda erkek öğretmen adayları lehine anlamlı bir farklılık olduğu görülmektedir. Eleştirel okuma öz yeterlik algı ölçeğinin diğer alt boyutlarında ise, kadınlar ile erkeklerin ortalamaları arasındaki farkın anlamlı olmadığı tespit edilmiştir. Bu sonuçlar cinsiyetin, Türkçe öğretmeni adaylarının eleştirel okuma öz yeterlik algıları üzerinde, "Görsel" alt boyutunda belirleyici bir faktör olduğu; "Değerlendirme" ve "Araştırma / İnceleme" alt boyutlarında ise, belirleyici bir faktör olmadığı şeklinde yorumlanabilir. Tablo 3 incelenmeye devam edildiğinde, motivasyon ölçeğinin "Benlik" alt boyutunda, kadın öğretmen adayları lehine anlamlı bir fark olduğu görülmektedir. Ölçeğin "Yeterlilik", "Tanınma” ve "Diğer” alt boyutlarında ise, kadınlar ile erkeklerin ortalamaları arasındaki farkın anlamlı olmadığı tespit edilmiştir. Bu sonuçlar cinsiyetin, Türkçe öğretmeni adaylarının okuma motivasyonları üzerinde, "Benlik" alt boyutunda belirleyici bir faktör olduğu; "Yeterlilik", "Tanınma" ve "Diğer" alt boyutlarında ise, belirleyici bir faktör olmadığı şeklinde yorumlanabilir.

Türkçe öğretmeni adaylarının eleştirel okuma öz yeterlik algılarının ve okuma motivasyonlarının öğrenim görmekte oldukları sınıf değişkenine göre incelenmesi

Bu bölümde; Türkçe öğretmeni adaylarının eleştirel okuma öz yeterlik algılarının ve okuma motivasyonlarının öğrenim görmekte oldukları sınıf değişkenine göre anlamlı bir şekilde farklılaşıp farklılaşmadığı araştııılmıştır. Bunun için Türkçe öğretmeni adaylarının ölçeklere vermiş oldukları cevaplar üzerinde tek faktörlü varyans analizi uygulanmıştır. İlgili analizden elde edilen sonuçlar Tablo 4'te gösterilmiştir. 
Tablo 4. Türkçe Öğretmeni Adaylarının Eleştirel Okuma Öz Yeterlik Algılarının ve Okuma Motivasyonlarının Öğrenim Görmekte Oldukları Sınıfa Göre Farklılaşıp Farklılaşmadığına İlişkin Analiz Sonuçları

\begin{tabular}{|c|c|c|c|c|c|c|c|c|}
\hline & Sinif & $\mathbf{N}$ & $X^{-}$ & S.s & sd & $\mathbf{F}$ & $\mathbf{p}$ & $\begin{array}{l}\text { Anlamlı } \\
\text { Fark }\end{array}$ \\
\hline \multirow{4}{*}{$\begin{array}{l}\text { Eleştirel Okuma } \\
\text { Değerlendirme Alt Boyutu }\end{array}$} & 1. Sinıf & 42 & 3,78 &, 556 & \multirow[t]{4}{*}{$3 / 202$} & \multirow[t]{4}{*}{1,141} & \multirow[t]{4}{*}{334} & \multirow[t]{4}{*}{---} \\
\hline & 2. Sinıf & 60 & 3,86 &, 560 & & & & \\
\hline & 3. Sinıf & 52 & 3,97 &, 523 & & & & \\
\hline & 4. Sinıf & 52 & 3,93 & ,570 & & & & \\
\hline \multirow{4}{*}{$\begin{array}{l}\text { Eleştirel Okuma Araştırma } \\
\text { / İnceleme Alt Boyutu }\end{array}$} & 1. Sinıf & 42 & 3,67 & ,658 & \multirow[t]{4}{*}{$3 / 202$} & \multirow[t]{4}{*}{,892 } & \multirow[t]{4}{*}{,446 } & \multirow[t]{4}{*}{---} \\
\hline & 2. Sinıf & 60 & 3,83 &, 522 & & & & \\
\hline & 3. Sinıf & 52 & 3,81 &, 545 & & & & \\
\hline & 4. Sinıf & 52 & 3,83 &, 512 & & & & \\
\hline \multirow{4}{*}{$\begin{array}{l}\text { Eleştirel Okuma Görsel Alt } \\
\text { Boyutu }\end{array}$} & 1. Sinif & 42 & 3,34 &, 738 & \multirow[t]{4}{*}{$3 / 202$} & \multirow[t]{4}{*}{,232 } & \multirow[t]{4}{*}{,874 } & \multirow[t]{4}{*}{---} \\
\hline & 2. Sinif & 60 & 3,42 & ,688 & & & & \\
\hline & 3. Sinif & 52 & 3,36 & 672 & & & & \\
\hline & 4. Sinif & 52 & 3,45 &, 760 & & & & \\
\hline \multirow{4}{*}{$\begin{array}{l}\text { Motivasyon Ölçeği Benlik } \\
\text { Alt Boyutu }\end{array}$} & 1. Sinıf & 42 & 3,84 &, 552 & \multirow[t]{4}{*}{$3 / 202$} & \multirow[t]{4}{*}{, 566} & \multirow[t]{4}{*}{638} & \multirow[t]{4}{*}{---} \\
\hline & 2. Sinıf & 60 & 3,97 & ,484 & & & & \\
\hline & 3. Sinıf & 52 & 3,90 & ,539 & & & & \\
\hline & 4. Sinıf & 52 & 3,87 & ,466 & & & & \\
\hline \multirow{4}{*}{$\begin{array}{l}\text { Motivasyon Ölçeği } \\
\text { Yeterlilik Alt Boyutu }\end{array}$} & 1. Sinıf & 42 & 3,58 & ,675 & \multirow[t]{4}{*}{$3 / 202$} & \multirow[t]{4}{*}{,233 } & \multirow[t]{4}{*}{,873 } & \multirow[t]{4}{*}{---} \\
\hline & 2. Sinıf & 60 & 3,60 &, 560 & & & & \\
\hline & 3. Sinıf & 52 & 3,52 & ,663 & & & & \\
\hline & 4. Sinıf & 52 & $3,5^{2}$ & ,611 & & & & \\
\hline \multirow{4}{*}{$\begin{array}{l}\text { Motivasyon Ölçeği } \\
\text { Tanınma Alt Boyutu }\end{array}$} & 1. Sinif & 42 & 3,20 & ,805 & \multirow[t]{4}{*}{$3 / 202$} & \multirow[t]{4}{*}{3,782} & \multirow[t]{4}{*}{,011 } & \multirow[t]{4}{*}{$2-4$} \\
\hline & 2. Sinıf & 60 & 3,62 & ,995 & & & & \\
\hline & 3. Sinıf & 52 & 3,23 & 1,00 & & & & \\
\hline & 4. Sinıf & 52 & 3,05 & ,906 & & & & \\
\hline Motivasyon Ölçeği Diğer & 1. Sinıf & 42 & 3,74 & 601 & $3 / 202$ & ,396 &, 756 & --- \\
\hline & 2. Sinif & 60 & 3,65 &, 736 & & & & \\
\hline & 3. Sinıf & 52 & 3,77 &, 705 & & & & \\
\hline & 4. Sinıf & 52 & 3,68 & ,615 & & & & \\
\hline
\end{tabular}

Türkçe öğretmeni adaylarının eleştirel okuma öz yeterlik algılarının öğrenim görmekte oldukları sınıf düzeyine göre anlamlı olarak farklılaşıp farklılaşmadığını belirlemek için yapılan tek faktörlü ANOVA sonucunda aradaki farkın "Değerlendirme" $\left(\mathrm{F}_{202}=1,141, \mathrm{p}>.05\right)$, "Araştırma / İnceleme" $\left(\mathrm{F}_{202}=, 892\right.$, p >.05) ve "Görsel" ( $\left.\mathrm{F}_{202}=, 232, \mathrm{p}>.05\right)$ alt boyutlarında, anlamlı olmadığı bulunmuştur. Buna göre; Türkçe öğretmeni adaylarının öğrenim görmekte oldukları sınıf düzeyinin, eleştirel okuma öz yeterlik algıları üzerinde anlamlı bir etki oluşturmadığı söylenebilir.

Türkçe öğretmeni adaylarının okumaya yönelik motivasyon düzeylerinin öğrenim görmekte oldukları sınıf düzeyine göre anlamlı olarak farklılaşıp farklılaşmadığını belirlemek için yapılan tek faktörlü 
An analysis of the correlation between critical reading self-sufficiency perceptions and reading motivations of Turkish teacher candidates / N. Şahin (p. 214-233)

ANOVA sonucunda aradaki farkın "Tanınma" $\left(\mathrm{F}_{202}=3,782, \mathrm{p}<.05\right)$ alt boyutunda anlamlı olduğu bulunmuştur. Farkın hangi ortalamalar arasında olduğunu belirlemek için çoklu karşılaştırma testlerinden "Tukey" testi uygulanmış ve 2. sınıf seviyesinde öğrenim görmekte olan Türkçe öğretmeni adaylarının okuma motivasyonlarının 4. sınıfta öğrenim görmekte olanlara göre anlamlı düzeyde arttı̆̆ tespit edilmiştir. Buna göre sınıf düzeyi, "Tanınma" alt boyutunda, okumaya yönelik motivasyonu etkileyen bir faktör olarak değerlendirilebilir. "Benlik" $\left(F_{202}=, 566, p>.05\right)$, "Yeterlilik" $\left(F_{202}=, 233\right.$, $\mathrm{p}>$.05) ve "Diğer" ( $\left.\mathrm{F}_{202}=, 396, \mathrm{p}>.05\right)$ alt boyutlarında ise, gruplar arasındaki farkın anlamlı olmadığı bulunmuştur. Buna göre; sınıf düzeyinin, "Benlik", "Yeterlilik" ve "Diğer" alt boyutlarında, Türkçe öğretmeni adaylarının okuma motivasyonlarını etkileyen bir faktör olmadığı söylenebilir.

\section{Türkçe öğretmeni adaylarının eleştirel okuma öz yeterlik algılarının ve okuma motivasyonlarının kendilerine ait kitaplıklarının bulunup bulunmamasına göre incelenmesi}

Bu bölümde; Türkçe öğretmeni adaylarının eleştirel okuma öz yeterlik algılarının ve okuma motivasyonlarının kendilerine ait kitaplıklarının bulunup bulunmamasına göre anlamlı bir şekilde farklılaşıp farklılaşmadığı araştırılmıştır. Bunun için Türkçe öğretmeni adaylarının ölçeklere vermiş oldukları cevaplar bağımsız örneklem t- testi ile analiz edilmiştir. İlgili analizden elde edilen sonuçlar Tablo 5'te gösterilmiştir.

Tablo 5. Türkçe Öğretmeni Adaylarının Eleştirel Okuma Öz Yeterlik Algılarının ve Okuma Motivasyonlarının Kendilerine Ait Kitaplıklarının Bulunup Bulunmamasına Göre Farklılaşıp Farklılaşmadığına İlişkin Analiz Sonuçları

\begin{tabular}{|c|c|c|c|c|c|c|}
\hline & & $\mathbf{N}$ & $\mathbf{X}$ & S.S & $\mathbf{t}$ & $\mathbf{p}$ \\
\hline \multirow[t]{2}{*}{ Eleştirel Okuma Değerlendirme Alt Boyutu } & Var & 118 & 3,97 &, 527 & \multirow[t]{2}{*}{2,334} & \multirow[t]{2}{*}{,021 } \\
\hline & Yok & 88 & 3,79 & ,574 & & \\
\hline \multirow{2}{*}{$\begin{array}{l}\text { Eleştirel Okuma Araştırma / İnceleme Alt } \\
\text { Boyutu }\end{array}$} & Var & 118 & 3,86 &, 538 & \multirow[t]{2}{*}{2,070} & \multirow[t]{2}{*}{,040 } \\
\hline & Yok & 88 & 3,70 &, 568 & & \\
\hline \multirow[t]{2}{*}{ Eleştirel Okuma Görsel Alt Boyutu } & Var & 118 & 3,43 & ,711 & \multirow[t]{2}{*}{,919 } & \multirow[t]{2}{*}{,359 } \\
\hline & Yok & 88 & 3,34 &, 708 & & \\
\hline \multirow[t]{2}{*}{ Motivasyon Ölçeği Benlik Alt Boyutu } & Var & 118 & 3,96 &, 511 & \multirow[t]{2}{*}{1,813} & \multirow[t]{2}{*}{, 071} \\
\hline & Yok & 88 & 3,83 & ,494 & & \\
\hline \multirow[t]{2}{*}{ Motivasyon Ölçeği Yeterlilik Alt Boyutu } & Var & 118 & 3,62 & ,630 & \multirow[t]{2}{*}{1,616} & \multirow[t]{2}{*}{,108 } \\
\hline & Yok & 88 & 3,48 & ,601 & & \\
\hline \multirow[t]{2}{*}{ Motivasyon Ölçeği Tanınma Alt Boyutu } & Var & 118 & 3,24 & ,893 & \multirow[t]{2}{*}{,- 876} & \multirow[t]{2}{*}{, 382} \\
\hline & Yok & 88 & 3,36 & 1,04 & & \\
\hline \multirow[t]{2}{*}{ Motivasyon Ölçeği Diğer Alt Boyutu } & Var & 118 & 3,74 & 659 & \multirow[t]{2}{*}{,772 } & \multirow[t]{2}{*}{,441 } \\
\hline & Yok & 88 & 3,66 & 686 & & \\
\hline
\end{tabular}

Tablo 5 incelendiğinde; eleştirel okuma öz yeterlik algı ölçeğinin "Değerlendirme" ve "Araştırma / İnceleme" alt boyutlarında kendilerine ait kitaplıkları bulunan öğretmen adayları lehine anlamlı bir farklılık olduğu görülmektedir. Eleştirel okuma öz yeterlik algı ölçeğinin "Görsel” alt boyutunda ise, grupların ortalamaları arasındaki farkın anlamlı olmadığı tespit edilmiştir. Bu sonuçlar kendine ait kitaplığı bulunup bulunmamasının, Türkçe öğretmeni adaylarının eleştirel okuma öz yeterlik algıları üzerinde, "Değerlendirme" ve "Araştırma / İnceleme" alt boyutlarında belirleyici bir faktör olduğu; 
"Görsel” alt boyutunda ise, belirleyici bir faktör olmadığı şeklinde yorumlanabilir. Tablo 5 incelenmeye devam edildiğinde, motivasyon ölçeğinin tüm alt boyutlarında, kendilerine ait kitaplığı bulunanlar ile bulunmayanların ortalamaları arasındaki farkın anlamlı olmadığı tespit edilmiştir. Bu sonuçlar kendine ait kitaplığı bulunup bulunmaması değişkeninin, Türkçe öğretmeni adaylarının okuma motivasyonları üzerinde, belirleyici bir faktör olmadığı şeklinde yorumlanabilir.

Türkçe öğretmeni adaylarının eleştirel okuma öz yeterlik algılarının ve okuma motivasyonlarının yılda okunan kitap sayısına göre incelenmesi

Bu bölümde; Türkçe öğretmeni adaylarının eleştirel okuma öz yeterlik algılarının ve okuma motivasyonlarının yılda okunan kitap sayısına göre anlamlı bir şekilde farklılaşıp farklılaşmadığı araştırılmıştır. Bunun için Türkçe öğretmeni adaylarının ölçeklere vermiş oldukları cevaplar üzerinde tek faktörlü varyans analizi uygulanmıştır. İlgili analizden elde edilen sonuçlar Tablo 6'da gösterilmiştir.

Tablo 6. Türkçe Öğretmeni Adaylarının Eleştirel Okuma Öz Yeterlik Algılarının ve Okuma Motivasyonlarının Yılda Okunan Kitap Sayısına Göre Farklılaşıp Farklılaşmadığına İlişkin Analiz Sonuçları

\begin{tabular}{|c|c|c|c|c|c|c|c|c|}
\hline & Kitap Sayısı & $\mathbf{N}$ & $\mathbf{X}$ & S.s & sd & $\mathbf{F}$ & $\mathbf{p}$ & $\begin{array}{l}\text { Anlamlı } \\
\text { Fark }\end{array}$ \\
\hline \multirow{5}{*}{$\begin{array}{l}\text { Eleştirel } \\
\text { Okuma } \\
\text { Değerlendir } \\
\text { me Alt } \\
\text { Boyutu }\end{array}$} & Hiç (A) & 5 & 3,45 & ,480 & \multirow[t]{5}{*}{$4 / 201$} & \multirow[t]{5}{*}{7,933} & \multirow[t]{5}{*}{, OOO } & \multirow{5}{*}{$\begin{array}{l}\text { E-A } \\
\text { C-B } \\
\text { D-B } \\
\text { E-B }\end{array}$} \\
\hline & 1-3 Adet (B) & 32 & 3,49 & ,536 & & & & \\
\hline & 4-7 Adet (C) & 65 & 3,92 &, 535 & & & & \\
\hline & 8-10 Adet (D) & 46 & 3,91 &, 583 & & & & \\
\hline & 10 Üzeri (E) & 58 & 4,10 & ,434 & & & & \\
\hline \multirow{5}{*}{$\begin{array}{l}\text { Eleştirel } \\
\text { Okuma } \\
\text { Araştırma / } \\
\text { İnceleme Alt } \\
\text { Boyutu }\end{array}$} & Hiç (A) & 5 & 3,39 &, 584 & \multirow[t]{5}{*}{$4 / 201$} & \multirow[t]{5}{*}{4,230} & \multirow[t]{5}{*}{,o03 } & \multirow{5}{*}{$\begin{array}{l}\text { E-A } \\
\text { C-B } \\
\text { E-B } \\
\text { E-D }\end{array}$} \\
\hline & 1-3 Adet (B) & 32 & 3,54 & 566 & & & & \\
\hline & 4-7 Adet (C) & 65 & 3,79 &, 527 & & & & \\
\hline & 8-10 Adet (D) & 46 & 3,77 &, 584 & & & & \\
\hline & 10 Üzeri (E) & 58 & 3,98 & ,493 & & & & \\
\hline \multirow{5}{*}{$\begin{array}{l}\text { Eleştirel } \\
\text { Okuma } \\
\text { Görsel Alt } \\
\text { Boyutu }\end{array}$} & Hiç (A) & 5 & 3,32 &, 756 & \multirow[t]{5}{*}{$4 / 201$} & \multirow[t]{5}{*}{2,953} & \multirow[t]{5}{*}{,021 } & \multirow{5}{*}{$\begin{array}{l}\text { C-B } \\
\text { D-B } \\
\text { E-B }\end{array}$} \\
\hline & 1-3 Adet (B) & 32 & 3,06 & ,722 & & & & \\
\hline & 4-7 Adet (C) & 65 & 3,38 &, 700 & & & & \\
\hline & 8-10 Adet (D) & 46 & 3,41 &, 787 & & & & \\
\hline & 10 Üzeri (E) & 58 & 3,58 &, 588 & & & & \\
\hline \multirow{5}{*}{$\begin{array}{l}\text { Motivasyon } \\
\text { Ölçeği Benlik } \\
\text { Alt Boyutu }\end{array}$} & Hiç (A) & 5 & 3,07 & ,488 & \multirow[t]{5}{*}{$4 / 201$} & \multirow[t]{5}{*}{14,783} & \multirow[t]{5}{*}{,ooo } & \multirow{5}{*}{$\begin{array}{l}\text { B-A / C-A } \\
\text { D-A / E-A } \\
\text { C-B / D-B } \\
\text { E-B / E-C } \\
\text { E-D / }\end{array}$} \\
\hline & 1-3 Adet (B) & 32 & 3,58 &, 460 & & & & \\
\hline & 4-7 Adet (C) & 65 & 3,82 & ,455 & & & & \\
\hline & 8-1o Adet (D) & 46 & 3,97 & ,459 & & & & \\
\hline & 10 Üzeri (E) & 58 & 4,18 & ,427 & & & & \\
\hline \multirow{4}{*}{$\begin{array}{l}\text { Motivasyon } \\
\text { Ölçeği } \\
\text { Yeterlilik Alt } \\
\text { Boyutu }\end{array}$} & Hiç (A) & 5 & 3,40 &, 547 & \multirow[t]{4}{*}{$4 / 201$} & \multirow[t]{4}{*}{3,925} & \multirow[t]{4}{*}{,004 } & \multirow{4}{*}{$\begin{array}{l}\text { E-B } \\
\text { D-C } \\
\text { E-C }\end{array}$} \\
\hline & 1-3 Adet (B) & 32 & 3,39 &, 581 & & & & \\
\hline & 4-7 Adet (C) & 65 & 3,40 &, 705 & & & & \\
\hline & 8-10 Adet (D) & 46 & 3,65 &, 502 & & & & \\
\hline
\end{tabular}




\begin{tabular}{|c|c|c|c|c|c|c|c|c|}
\hline & 10 Üzeri (E) & 58 & 3,78 &, 567 & & & & \\
\hline \multirow{5}{*}{$\begin{array}{l}\text { Motivasyon } \\
\text { Ölçeği } \\
\text { Tanınma Alt } \\
\text { Boyutu }\end{array}$} & Hiç (A) & 5 & 2,80 & 1,04 & \multirow[t]{5}{*}{$4 / 201$} & \multirow[t]{5}{*}{1,987} & \multirow[t]{5}{*}{,098 } & \multirow[t]{5}{*}{---} \\
\hline & 1-3 Adet (B) & 32 & 3,68 & ,965 & & & & \\
\hline & 4-7 Adet (C) & 65 & 3,30 & ,983 & & & & \\
\hline & 8-10 Adet (D) & 46 & 3,16 & ,966 & & & & \\
\hline & 10 Üzeri (E) & 58 & 3,22 & ,883 & & & & \\
\hline \multirow{5}{*}{$\begin{array}{l}\text { Motivasyon } \\
\text { Ölçeği Diğer } \\
\text { Alt Boyutu }\end{array}$} & Hiç (A) & 5 & 2,99 & ,847 & \multirow[t]{5}{*}{$4 / 201$} & \multirow[t]{5}{*}{2,730} & \multirow[t]{5}{*}{,030 } & \multirow{5}{*}{$\begin{array}{l}\text { C-A } \\
\text { D-A } \\
\text { E-A } \\
\text { E-B }\end{array}$} \\
\hline & 1-3 Adet (B) & 32 & 3,56 &, 753 & & & & \\
\hline & 4-7 Adet (C) & 65 & 3,74 & ,667 & & & & \\
\hline & 8-10 Adet (D) & 46 & 3,65 & 606 & & & & \\
\hline & 10 Üzeri (E) & 58 & 3,85 & ,616 & & & & \\
\hline
\end{tabular}

Tabloya göre; Türkçe öğretmeni adaylarının “Değerlendirme” alt boyutunda, eleştirel okuma öz yeterlik algılarının yılda okunan kitap sayısına göre anlamlı olarak farklılaşıp farklılaşmadığını belirlemek için yapılan tek faktörlü ANOVA sonucunda aradaki farkın anlamlı olduğu bulunmuştur $\left(\mathrm{F}_{201}=7,933, \mathrm{p}<.05\right)$. Farkın hangi ortalamalar arasında olduğunu belirlemek için çoklu karşılaştırma testlerinden "Tukey" testi uygulanmış ve yll içerisinde "1-3 adet” bandında kitap okuyan öğretmen adaylarının eleştirel okuma öz yeterlik algılarının, daha fazla kitap okuyanlara göre anlamlı düzeyde azaldığı görülmüştür. Ayrıca yılda "10 üzeri" kitap okuyan öğretmen adaylarının eleştirel okuma öz yeterlik algılarının, hiç kitap okumayanlara göre anlamlı şekilde artı̆̆ bulunmuştur. Buna göre yıl içerisinde okunan kitap sayısı, "Değerlendirme" alt boyutunda, eleştirel okuma öz yeterlik algısını pozitif yönde etkileyen bir faktör olarak değerlendirilebilir.

Tabloya göre; Türkçe öğretmeni adaylarının “Araştırma / İnceleme” alt boyutunda, eleştirel okuma öz yeterlik algılarının yılda okunan kitap sayısına göre anlamlı olarak farklılaşıp farklılaşmadığını belirlemek için yapılan tek faktörlü ANOVA sonucunda aradaki farkın anlamlı olduğu bulunmuştur $\left(\mathrm{F}_{201}=4,230, \mathrm{p}<.05\right)$. Farkın hangi ortalamalar arasında olduğunu belirlemek için çoklu karşılaştırma testlerinden "Tukey" testi uygulanmış ve yll içerisinde hiç kitap okumayan öğretmen adaylarının eleştirel okuma öz yeterlik algılarının, "10 üzeri” kitap okuyanlara göre anlamlı düzeyde azaldığı görülmüş̧ür. Ayrıca "1-3 adet” bandında kitap okuyan öğretmen adaylarının eleştirel okuma öz yeterlik algılarının ise, 4 ve daha fazla kitap okuyanlara göre anlamlı düzeyde azaldığı görülmüsstür. Buna göre yl içerisinde okunan kitap sayısı, "Araştırma / İnceleme" alt boyutunda, eleştirel okuma öz yeterlik algısını etkileyen bir faktör olarak değerlendirilebilir.

Tabloya göre; Türkçe öğretmeni adaylarının "Görsel” alt boyutunda, eleştirel okuma öz yeterlik algılarının yılda okunan kitap sayısına göre anlamlı olarak farklılaşıp farklılaşmadığını belirlemek için yapılan tek faktörlü ANOVA sonucunda aradaki farkın anlamlı olduğu bulunmuştur $\left(\mathrm{F}_{201}=2,953, \mathrm{p}<.05\right)$. Farkın hangi ortalamalar arasında olduğunu belirlemek için çoklu karşılaştırma testlerinden "Tukey" testi uygulanmış ve "1-3 adet" bandında kitap okuyan öğretmen adaylarının eleştirel okuma öz yeterlik algılarının, 4 ve daha fazla kitap okuyanlara göre anlamlı düzeyde azaldığı görülmüsstür. Buna göre yıl içerisinde okunan kitap sayısı, "Görsel” alt boyutunda, eleştirel okuma öz yeterlik algısını etkileyen bir faktör olarak değerlendirilebilir.

Tabloya göre; Türkçe öğretmeni adaylarının "Benlik” alt boyutunda, okumaya yönelik motivasyon düzeylerinin yılda okunan kitap sayısına göre anlamlı olarak farklılaşıp farklılaşmadığını belirlemek için 
yapılan tek faktörlü ANOVA sonucunda aradaki farkın anlamlı olduğu bulunmuştur $\left(F_{201}=14,783\right.$, p<.05). Farkın hangi ortalamalar arasında olduğunu belirlemek için çoklu karşılaştırma testlerinden "Tukey" testi uygulanmış ve yll içerisinde hiç kitap okumayan öğretmen adaylarının okumaya yönelik motivasyon düzeylerinin 1 ve daha fazla kitap okuyanlara göre anlamlı düzeyde azaldığı görülmüştür. "1-3 adet" bandında kitap okuyan öğretmen adaylarının ise, 4 ve daha fazla kitap okuyanlara göre okuma motivasyonlarının anlamlı düzeyde azaldığı görülmüştür. Son olarak "4-7 adet" ve "8-10 adet" bandında kitap okuyan öğretmen adaylarının "Benlik" alt boyutunda okumaya yönelik motivasyon düzeylerinin "10 üzeri” bandında okuyanlara göre anlamlı düzeyde azaldı̆̆ bakıldığında, yıl içerisinde okunan kitap sayısı arttıkça, "Benlik" alt boyutunda, okuma motivasyonu düzeyi de anlamlı bir şekilde artmaktadır. Buna göre yıl içerisinde okunan kitap sayısı, "Benlik” alt boyutunda, okumaya yönelik motivasyonu etkileyen bir faktör olarak değerlendirilebilir.

Tabloya göre; Türkçe öğretmeni adaylarının "Yeterlilik" alt boyutunda, okumaya yönelik motivasyon düzeylerinin yılda okunan kitap sayısına göre anlamlı olarak farklılaşıp farklılaşmadığını belirlemek için yapılan tek faktörlü ANOVA sonucunda aradaki farkın anlamlı olduğu bulunmuştur $\left(\mathrm{F}_{201}=3,925, \mathrm{p}<.05\right)$. Farkın hangi ortalamalar arasında olduğunu belirlemek için çoklu karşılaştırma testlerinden "Tukey" testi uygulanmış ve yl içerisinde "4-7 adet" kitap okuyan öğretmen adaylarının "Yeterlilik" alt boyutunda okumaya yönelik motivasyon düzeylerinin daha fazla kitap okuyanlara göre anlamlı düzeyde azaldığı görülmüştür. Ayrıca, "10 üzeri” bandında kitap okuyan öğretmen adaylarının ise, "1-3 adet" bandında kitap okuyanlara göre okuma motivasyonlarının anlamlı düzeyde arttığı görülmüştür. Buna göre yıl içerisinde okunan kitap sayısı, "Yeterlilik" alt boyutunda, okumaya yönelik motivasyonu etkileyen bir faktör olarak değerlendirilebilir.

Tabloya göre; Türkçe öğretmeni adaylarının "Tanınma" alt boyutunda, okumaya yönelik motivasyon düzeylerinin yılda okunan kitap sayısına göre anlamlı olarak farklılaşıp farklılaşmadığını belirlemek için yapılan tek faktörlü ANOVA sonucunda aradaki farkın anlamlı olmadığı bulunmuştur $\left(F_{201}=1,987\right.$, $\mathrm{p}<.05$ ). Buna göre yıl içerisinde okunan kitap sayısının, "Tanınma" alt boyutunda, okumaya yönelik motivasyonu etkileyen bir faktör olmadığı söylenebilir.

Tabloya göre; Türkçe öğretmeni adaylarının "Diğer" alt boyutunda, okumaya yönelik motivasyon düzeylerinin yılda okunan kitap sayısına göre anlamlı olarak farklılaşıp farklılaşmadığını belirlemek için yapılan tek faktörlü ANOVA sonucunda aradaki farkın anlamlı olduğu bulunmuştur $\left(\mathrm{F}_{201}=2,730\right.$, p<.05). Farkın hangi ortalamalar arasında olduğunu belirlemek için çoklu karşılaştırma testlerinden "Tukey" testi uygulanmış ve yll içerisinde hiç kitap okumayan öğretmen adaylarının "Diğer" alt boyutunda okumaya yönelik motivasyon düzeylerinin 4 ve daha fazla kitap okuyanlara göre anlaml düzeyde azaldığı görülmüştür. Ayrıca, "10 üzeri” bandında kitap okuyan öğretmen adaylarının ise, "1-3 adet” bandında kitap okuyanlara göre okuma motivasyonlarının anlamlı düzeyde arttı̆̆ı tespit edilmiştir. Buna göre yll içerisinde okunan kitap sayısı, "Diğer" alt boyutunda, okumaya yönelik motivasyonu etkileyen bir faktör olarak değerlendirilebilir.

\section{Türkçe öğretmeni adaylarının eleştirel okuma öz yeterlik algıları ve okuma motivasyonları arasındaki ilişki}

Bu bölümde; Türkçe öğretmeni adaylarının eleştirel okuma öz yeterlik algıları ile okuma motivasyonları arasında anlamlı bir ilişki olup olmadığı araştırılmıştır. Bunun için Türkçe öğretmeni adaylarının ölçeklere vermiş oldukları cevaplar Pearson korelasyon analizi ile analiz edilmiştir. İlgili analizden elde edilen sonuçlar aşağıda tablolar hâlinde gösterilmiştir. 
An analysis of the correlation between critical reading self-sufficiency perceptions and reading motivations of Turkish teacher candidates / N. Şahin (p. 214-233)

Eleştirel okuma öz yeterlik algı ölçeğinin alt boyutlarından biri olan "Değerlendirme” alt boyutunun, motivasyon ölçeğinin alt boyutlarıyla olan ilişkilerini tespit etmek amacıyla yapılan Pearson korelasyon analizinden elde edilen sonuçlar Tablo 7'de gösterilmiştir.

Tablo 7. Türkçe Öğretmeni Adaylarının “Değerlendirme” Alt Boyutunda, Eleştirel Okuma Öz Yeterlik Algılarının Motivasyon Ölçeğinin Alt Boyutları İle Olan İlişkisi

\begin{tabular}{lcccc} 
& \multicolumn{1}{c}{$\begin{array}{c}\text { Motivasyon } \\
\text { Benlik }\end{array}$} & $\begin{array}{c}\text { Motivasyon } \\
\text { Yeterlilik }\end{array}$ & $\begin{array}{c}\text { Motivasyon } \\
\text { Tanınma }\end{array}$ & $\begin{array}{c}\text { Motivasyon } \\
\text { Diğer }\end{array}$ \\
\hline $\begin{array}{l}\text { Eleștirel Okuma Öz } \\
\text { Yeterlik Algı - } \\
\text { Değgrlendirme }\end{array}$ &, 487 &, 391 &, 035 &, 281 \\
\hline
\end{tabular}

Tablo 7 incelendiğinde; Türkçe öğretmeni adaylarının "Değerlendirme" alt boyutunda almış oldukları eleştirel okuma öz yeterlik algı puanları ile "Benlik", "Yeterlilik", "Tanınma” ve "Diğer" alt boyutlarında almış oldukları okuma motivasyonu puanları arasında anlamlı bir ilişki olup olmadığını belirlemek için yapılan Pearson korelasyon analizi sonucunda eleştirel okuma öz yeterlik algı ölçeğinin "Değerlendirme" alt boyutu ile "Motivasyon Benlik" ( $\mathrm{r}=, 487, \mathrm{p}<.01)$ alt boyutu arasında pozitif yönlü orta düzeyde bir ilişki; "Motivasyon Yeterlilik" ( $\mathrm{r}=, 391, \mathrm{p}<.01)$ ve "Motivasyon Diğer" $(\mathrm{r}=, 281, \mathrm{p}<.01)$ alt boyutları arasında ise, pozitif yönde zayıf düzeyde bir ilişki olduğu görülmüştür. Buna göre; Türkçe öğretmeni adaylarının "Değerlendirme" alt boyutunda, eleştirel okuma öz yeterlik algı puanlarının artması durumunda "Motivasyon Benlik", "Motivasyon Yeterlilik" ve "Motivasyon Diğer" puanlarının da artacağı söylenebilir. Öte taraftan Tablo 7 incelenmeye devam edildiğinde, Türkçe öğretmeni adaylarının eleştirel okuma öz yeterlik algı ölçeğinin "Değerlendirme" alt boyutu ile motivasyon ölçeğinin "Tanınma" $(r=, 035, p>.05)$ alt boyutundan almış oldukları puanlar arasında anlamlı bir ilişki olmadığı tespit edilmiştir.

Eleştirel okuma öz yeterlik algı ölçeğinin alt boyutlarından biri olan "Araştırma / İnceleme" alt boyutunun, motivasyon ölçeğinin alt boyutlarıyla olan ilişkilerini tespit etmek amacıyla yapılan Pearson korelasyon analizinden elde edilen sonuçlar Tablo 8'de gösterilmiştir.

Tablo 8. Türkçe Öğretmeni Adaylarının “Araştırma / İnceleme” Alt Boyutunda, Eleştirel Okuma Öz Yeterlik Algılarının Motivasyon Ölçeğinin Alt Boyutları İle Olan İlişkisi

\begin{tabular}{lcccc}
\hline & $\begin{array}{c}\text { Motivasyon } \\
\text { Benlik }\end{array}$ & $\begin{array}{c}\text { Motivasyon } \\
\text { Yeterlilik }\end{array}$ & $\begin{array}{c}\text { Motivasyon } \\
\text { Tanınma }\end{array}$ & $\begin{array}{c}\text { Motivasyon } \\
\text { Diğer }\end{array}$ \\
\hline $\begin{array}{l}\text { Eleştirel Okuma Öz } \\
\text { Yeterlik Algı - }\end{array}$ &, 476 &, 428 &, 124 &, 261 \\
Araştırma / İnceleme & & & & \\
\hline
\end{tabular}

Tablo 8 incelendiğinde; Türkçe öğretmeni adaylarının "Araştırma / İnceleme” alt boyutunda almış oldukları eleştirel okuma öz yeterlik algı puanları ile "Benlik", "Yeterlilik", "Tanınma" ve "Diğer" alt boyutlarında almış oldukları okuma motivasyonu puanları arasında anlamlı bir ilişki olup olmadığını belirlemek için yapılan Pearson korelasyon analizi sonucunda eleştirel okuma öz yeterlik algı ölçeğinin "Araştırma / İnceleme" alt boyutu ile "Motivasyon Benlik" ( $\mathrm{r}=, 476, \mathrm{p}<.01)$ ve "Motivasyon Yeterlilik" $(\mathrm{r}=, 428, \mathrm{p}<.01)$ alt boyutları arasında pozitif yönlü orta düzeyde bir ilişki; "Motivasyon Diğer" ( $\mathrm{r}=, 261$, $\mathrm{p}<.01)$ alt boyutu arasında ise, pozitif yönde zayıf düzeyde bir ilişki olduğu görülmüştür. Buna göre; Türkçe öğretmeni adaylarının "Araştırma / İnceleme" alt boyutunda, eleştirel okuma öz yeterlik algı puanlarının artması durumunda "Motivasyon Benlik", "Motivasyon Yeterlilik" ve "Motivasyon Diğer" puanlarının da artacağı söylenebilir. Öte taraftan Tablo 8 incelenmeye devam edildiğinde, Türkçe öğretmeni adaylarının eleştirel okuma öz yeterlik algı ölçeğinin "Araştırma / İnceleme” alt boyutu ile 
motivasyon ölçeğinin “Tanınma”( $(r=, 124, \mathrm{p}>.05)$ alt boyutu arasında anlamlı bir ilişki olmadığı tespit edilmiştir.

Eleştirel okuma öz yeterlik algı ölçeğinin alt boyutlarından biri olan “Görsel” alt boyutunun, motivasyon ölçeğinin alt boyutlarıyla olan ilişkilerini tespit etmek amacıyla yapılan Pearson korelasyon analizinden elde edilen sonuçlar Tablo 9’da gösterilmiştir.

Tablo 9. Türkçe Öğretmeni Adaylarının "Görsel” Alt Boyutunda, Eleştirel Okuma Öz Yeterlik Algılarının Motivasyon Ölçeğinin Alt Boyutları Ile Olan İlişkisi

\begin{tabular}{lllll}
\hline & $\begin{array}{l}\text { Motivasyon } \\
\text { Benlik }\end{array}$ & $\begin{array}{l}\text { Motivasyon } \\
\text { Yeterlilik }\end{array}$ & $\begin{array}{l}\text { Motivasyon } \\
\text { Tanınma }\end{array}$ & $\begin{array}{l}\text { Motivasyon } \\
\text { Diğer }\end{array}$ \\
\hline $\begin{array}{l}\text { Eleştirel Okuma Öz } \\
\text { Yeterlik Algı - Görsel }\end{array}$ &, 299 &, 331 &, 042 &, 174 \\
\hline
\end{tabular}

Tablo 9 incelendiğinde; Türkçe öğretmeni adaylarının "Görsel" alt boyutunda almış oldukları eleştirel okuma öz yeterlik algı puanları ile "Benlik", "Yeterlilik", "Tanınma” ve "Diğer" alt boyutlarında almış oldukları okuma motivasyonu puanları arasında anlamlı bir ilişki olup olmadığını belirlemek için yapılan Pearson korelasyon analizi sonucunda eleştirel okuma öz yeterlik algı ölçeğinin "Görsel" alt boyutu ile "Motivasyon Benlik" ( $\mathrm{r}=, 299, \mathrm{p}<.01)$ ve "Motivasyon Yeterlilik" ( $\mathrm{r}=, 331, \mathrm{p}<.01)$ alt boyutları arasında pozitif yönlü zayıf düzeyde bir ilişki; "Motivasyon Diğer" $(\mathrm{r}=, 174, \mathrm{p}<.05)$ alt boyutu arasında ise, pozitif yönde çok zayıf düzeyde bir ilişki olduğu görülmüştür. Buna göre; Türkçe öğretmeni adaylarının "Görsel" alt boyutunda, eleştirel okuma öz yeterlik algı puanlarının artması durumunda "Motivasyon Benlik", "Motivasyon Yeterlilik" ve "Motivasyon Diğer" puanlarının da artacağı söylenebilir. Öte taraftan Tablo 9 incelenmeye devam edildiğinde, Türkçe öğretmeni adaylarının eleştirel okuma öz yeterlik algı ölçeğinin "Görsel” alt boyutu ile motivasyon ölçeğinin “Tanınma"( $\mathrm{r}=, 042$, p>.05) alt boyutu arasında anlamlı bir ilişki olmadığı tespit edilmiştir.

Son olarak Türkçe öğretmeni adaylarının genel eleştirel okuma öz yeterlik algıları ile genel okuma motivasyonları arasındaki ilişkiyi tespit etmek amacıyla yapılan Pearson korelasyon analizinden elde edilen sonuçlar Tablo 10’da gösterilmiştir.

Tablo 1o. Türkçe Öğretmeni Adaylarının Genel Eleştirel Okuma Öz Yeterlik Algıları ile Genel Okuma Motivasyonları Arasındaki İlişki

\begin{tabular}{lll}
\hline & & Okumaya Yönelik Genel Motivasyon Puanları \\
\hline $\begin{array}{l}\text { Eleştirel Okuma Öz Yeterli } \\
\text { Algıları Genel Puanları }\end{array}$ & $\mathrm{r}$ &, 461 \\
\cline { 2 - 3 } & $\mathrm{p}$ &, 000 \\
\cline { 2 - 3 } & $\mathrm{N}$ & 206 \\
\hline
\end{tabular}

Tablo 10 incelendiğinde; Türkçe öğretmeni adaylarının eleştirel okuma öz yeterlik algıları genel puanları ile okumaya yönelik genel motivasyon puanları arasında anlamlı bir ilişki olup olmadığını belirlemek için yapılan Pearson korelasyon analizi sonucunda eleştirel okuma öz yeterlik algıları ile okuma motivasyonları $(\mathrm{r}=, 461, \mathrm{p}<.01)$ arasında pozitif yönde ve orta düzeyde bir ilişki olduğu görülmüştür. Buna göre; Türkçe öğretmeni adaylarının eleştirel okuma öz yeterlik algı puanlarının artması durumunda okuma motivasyonu puanlarının da artacağı söylenebilir. 
An analysis of the correlation between critical reading self-sufficiency perceptions and reading motivations of Turkish teacher candidates / N. Şahin (p. 214-233)

\section{Sonuç ve öneriler}

Türkçe öğretmeni adaylarının eleştirel okuma öz yeterlik algıları ve okuma motivasyonları arasındaki ilişkiyi araştıran bu çalışmadan elde edilen sonuçlar aşağıda maddeler hâlinde sıralanmıştır.

- Türkçe öğretmeni adaylarının eleştirel okuma öz yeterlik algıları, "Görsel” alt boyutunda, erkek öğretmen adayları lehine anlamlı bir şekilde farklılık gösterirken, diğer alt boyutlarda kadınlar ile erkeklerin ortalamaları arasındaki farkın anlamlı olmadığı tespit edilmiştir. Bu sonuçlar genel olarak yorumlandığında, cinsiyet faktörünün, Türkçe öğretmeni adaylarının eleştirel okuma öz yeterlik algıları üzerinde belirleyici bir faktör olmadı̆̆ şeklinde ifade edilebilir. Literatür incelendiğinde, Aşılığlu ve Yaman (2017), öğretmen adaylarının eleştirel okuma öz yeterlik algılarını araştırdıkları çalışmalarında, cinsiyet faktörünün, "Değerlendirme" ve "Görsel" alt boyutlarında kadın öğretmen adayları lehine anlamlı bir şekilde farklılaştığını; "Araştırma / İnceleme" alt boyutunda ise, kadınlar ile erkeklerin ortalamaları arasında anlamlı bir farklılık olmadığını ifade etmişlerdir. Aynı şekilde, Epçaçan (2012) da, ortaokul öğrencileri ile gerçekleştirdiği çalışmasında, kız öğrencilerin eleştirel okuma becerilerinin erkeklere göre anlaml bir şekilde yüksek olduğunu tespit etmiştir. Topçuoğlu Ünal ve Sever (2013) ise, Türkçe öğretmeni adayları ile gerçekleştirdikleri araştırmalarında, cinsiyet faktörünün eleştirel okuma öz yeterlik algısı üzerinde belirleyici bir faktör olmadığı sonucuna ulaşmışlardır. Benzer şekilde, Aybek ve Aslan (2015) da cinsiyetin, öğretmen adaylarının eleştirel okuma öz yeterlik algllarını etkileyen bir faktör olmadığını tespit etmişlerdir. Özdemir (2017) ise, ortaokul öğrencilerinin eleştirel okuma öz yeterliklerini araştırdığı çalışmasında, cinsiyet faktörünün, erkek öğrenciler ile kız öğrencilerin ortalamaları arasında anlamlı bir farklılı̆ga sebep olmadığını tespit etmiştir.

- Türkçe öğretmeni adaylarının okuma motivasyonları, "Benlik" alt boyutunda, kadın öğretmen adayları lehine anlamlı bir şekilde farklılaşırken, diğer alt boyutlarda ise, kadınlar ile erkeklerin ortalamaları arasında anlamlı bir fark tespit edilememiştir. Bu sonuçlar, cinsiyetin, Türkçe öğretmeni adaylarının okuma motivasyonları üzerinde genel manada belirleyici bir faktör olmadığı şeklinde yorumlanabilir. Literatür incelendiğinde, kadınların erkeklere göre daha yüksek okuma motivasyonuna sahip olduklarına yönelik araştırmalar karşımıza çıkmaktadır. Örneğin; Yıldız (2013), 3., 4. ve 5. sınıflarla gerçekleştirdiği çalışmasında, öğrencilerin okuma motivasyonlarının, dışsal motivasyon boyutunda, kız öğrenciler lehine anlamlı bir şekilde farklılaştığı sonucuna ulaşmıştır. Katrancı (2015), Yıldız (2010), Kurnaz ve Yıldız (2015) ve Bozkurt ve Memiş (2013) çalışmaları da benzer sonuçlara işaret etmektedir.

- Türkçe öğretmeni adaylarının eleştirel okuma öz yeterlik algılarının, sınıf düzeyine göre anlamlı bir şekilde farklılaşmadığı bulunmuştur. Yani, öğrenim görülen sınıf düzeyi, Türkçe öğretmenlerinin eleştirel okuma öz yeterlik algıları üzerinde belirleyici bir faktör değildir. Literatür incelendiğinde, aynı sonuca, Aybek ve Aslan'ın (2015) da ulaştığını görmekteyiz. Aybek ve Aslan, kendi çalışmalarında, öğretmen adaylarının eleştirel okuma özyeterlik algıları ile sınıf düzeyleri arasında anlamlı fark olmadığını ifade etmişlerdir. Literatürde farklı türden sonuçların elde edildiği araştırmaları da görmek mümkündür. Örneğin; Topçuoğlu Ünal ve Sever’in (2013) Türkçe öğretmeni adayları ile gerçekleştirdiği çalışmasında, sınıf düzeyinin, eleştirel okuma öz yeterlik algısını anlamlı bir şekilde etkilediği ve 3. sınıfta öğrenim gören öğretmen adaylarının eleştirel okuma öz yeterlik algılarının, 4. sınıfta öğrenim görmekte olan öğretmen adaylarına göre anlamlı bir şekilde arttığı tespit edilmiştir. Benzer bir sonuç, Altunçekiç, Yaman ve Koray'ın (2005) çalışmasında da karşımıza çıkmaktadır.

- Türkçe öğretmeni adaylarının okuma motivasyonlarının, "Tanınma” alt boyutunda, sınıf düzeyine göre anlamlı bir şekilde farklılaştığı bulunmuştur. Yapılan testler sonucunda, 2. sınıf seviyesinde öğrenim görmekte olan Türkçe öğretmeni adaylarının okuma motivasyonlarının 4. sınıfta öğrenim görmekte olanlara göre anlamlı düzeyde arttığı tespit edilmiştir. Diğer alt boyutlarda ise, gruplar arasındaki farkın anlamlı olmadığı tespit edilmiştir. Bu sonuçlar, öğrenim görülen sınıf düzeyinin, Türkçe öğretmeni adaylarının okuma motivasyonları üzerinde genel manada belirleyici bir faktör olmadığı şeklinde yorumlanabilir. Literatür incelendiğinde, Yıldız (2013), sınıf düzeyi ile okuma motivasyonu arasında ters yönlü bir ilişki olduğunu ve sınıf seviyesi arttıkça okuma motivasyonunun azaldığını ifade etmiştir. Aynı şekilde, Epçaçan (2012) da, ortaokul öğrencileri ile gerçekleştirdiği çalışmasında, en düşük okuma motivasyonuna sahip öğrencilerin 8. sınıf 
öğrencileri olduğunu ifade etmişlerdir. Eccles, Wigfield ve Schiefele (1998), Wigfield, Eccles ve Rodriguez (1998) ve Wigfield ve Guthire (1997) gibi araştırmalarda da benzer sonuçları görmek mümkündür.

- Türkçe öğretmeni adaylarının eleştirel okuma öz yeterlik algıları, "Değerlendirme" ve "Araştırma / İnceleme" alt boyutlarında, kendilerine ait kitaplıkları bulunan öğretmen adayları lehine anlamlı bir şekilde farklılık gösterirken, "Görsel” alt boyutunda ise, grupların ortalamaları arasındaki farkın anlamlı olmadı̆̆ı tespit edilmiştir. Bu sonuçlar genel olarak yorumlandığında, kendine ait kitaplığı bulunup bulunmaması faktörünün, Türkçe öğretmeni adaylarının eleştirel okuma öz yeterlik algıları üzerinde belirleyici bir faktör olduğu şeklinde ifade edilebilir. Benzer şekilde, Aybek ve Aslan (2015) de, yaşadıkları evlerde kitaplık bulunup bulunmaması değișkeninin, öğretmen adaylarının eleştirel okuma öz yeterlik algıları üzerinde anlamlı bir etki oluşturduğu ve bu etkinin evlerinde kitaplık bulunan öğretmen adayları lehine olduğunu ifade etmişlerdir.

- Türkçe öğretmeni adaylarının okuma motivasyonları, tüm alt boyutlarında, kendilerine ait kitaplığı bulunanlar ile bulunmayanların ortalamaları arasındaki farkın anlamlı olmadığı tespit edilmiştir. Buna göre; kendine ait kitaplı̆̆ı bulunup bulunmaması değişkeninin, Türkçe öğretmeni adaylarının okuma motivasyonları üzerinde, belirleyici bir faktör olmadığı söylenebilir. Literatür incelendiğinde aksi yönde sonuçların elde edildiği araştırmalarla karşılaşmaktayız. Örneğin; Baker (2013), evde oluşturulabilecek olumlu okuma ortamlarının, okumaya yönelik istek, merak ve motivasyonunu artıracağını ifade etmiştir. Aynı şekilde Katrancı (2015), evde kendilerine ait kitaplığı olan öğrencilerin okuma motivasyonlarının, olmayanlara göre çok daha yüksek olduğunu tespit etmiştir. Kurnaz ve Yıldız (2015) ise, her ne kadar evlerinde kitaplık bulunan öğrencilerin okuma motivasyonları olmayanlara göre daha yüksek olsa da, aradaki bu farkın istatistiksel açıdan anlamlı olmadı̆̆ını ifade etmişlerdir.

- Türkçe öğretmeni adaylarının eleştirel okuma öz yeterlik algılarının, tüm alt boyutlarda, yılda okunan kitap sayısına göre anlamlı bir şekilde farklılaştığı tespit edilmiştir. Yapılan testler sonucunda, okunan kitap sayısının artmasının, Türkçe öğretmeni adaylarının eleştirel okuma öz yeterlik algılarını da genel manada artırdığı görülmüştür. Literatür incelendiğinde, Aşılıoğlu ve Yaman (2017) çalışmasında da, benzer bir sonuçla karşılaşmaktayız. Aşılıoğlu ve Yaman (2017), okunan kitap sayısı arttıkça, öğretmen adaylarının eleştirel okuma öz yeterlik algılarının da arttığını ifade etmişlerdir. Aynı şekilde, Topçuoğlu Ünal ve Sever (2013) de, her gün kitap okuyan Türkçe öğretmeni adaylarının eleştirel okuma öz yeterlik algılarının, diğer gruplarda yer alanlara göre anlamlı bir şekilde yüksek olduğunu tespit etmişlerdir. Bu bağlamda örnek gösterilebilecek bir diğer çalışma olan Aybek ve Aslan'nın (2015) çalışmasında ise, benzer bir şekilde, okunan kitap sayısının artması durumunda, öğretmen adaylarının eleştirel okuma öz yeterlik algılarının da anlamlı bir şekilde artacă̆ ifade edilmiştir.

- Türkçe öğretmeni adaylarının okuma motivasyonlarının, "Benlik", "Yeterlilik" ve "Diğer" alt boyutlarında, yılda okunan kitap sayısına göre anlamlı bir şekilde farklılaştığı tespit edilmiştir. "Tanınma" alt boyutunda ise, yılda okunan kitap sayısı değişkeninin, okuma motivasyonu üzerinde belirleyici bir rol oynamadığı görülmüştür. Yapılan çoklu karşılaştırma testi sonucunda, okunan kitap sayısı arttıkça, "Benlik", "Yeterlilik" ve "Diğer" alt boyutlarında Türkçe öğretmeni adaylarının okuma motivasyonlarının da genel mana da artacağı tespit edilmiştir. Literatürde yer alan Kurnaz ve Yıldız (2015) ve Ö̈ztürk ve İleri Aydemir (2013) çalışmalarında da aynı doğrultuda elde edilmiş sonuçlar görmek mümkündür. Adı geçen çalışmalarda da, okunan kitap sayısı ya da okumaya ayrılan süre arttıkça, okuma motivasyonunun da artacağı ifade edilmiştir.

Çalışmanın ana konusunu, Türkçe öğretmeni adaylarının eleştirel okuma öz yeterlik algıları ile okuma motivasyonları arasındaki ilişki oluşturmaktadır. Literatür incelendiğinde, bu bağlamda gerçekleştirilmiş bir araştırmaya rastlanılmamıştır. Yapılan analizler sonucunda ulaşılan sonuçlar aşağıda dikkatlere sunulmuşstur:

- Türkçe öğretmeni adaylarının, eleştirel okuma öz yeterlik algı ölçeğinin “Değerlendirme” alt boyutunda almış oldukları puanlar ile okuma motivasyonu ölçeğinin "Benlik" alt boyutu arasında pozitif yönlü orta düzeyde bir ilişki; "Yeterlilik" ve "Diğer" alt boyutları arasında ise, pozitif yönde zayıf düzeyde bir ilişki olduğu görülmüştür. Buna göre; Türkçe öğretmeni adaylarının "Değerlendirme" alt boyutunda, eleştirel okuma öz yeterlik algı puanlarının 
An analysis of the correlation between critical reading self-sufficiency perceptions and reading motivations of Turkish teacher candidates / N. Şahin (p. 214-233)

artması durumunda "Benlik", "Yeterlilik" ve "Diğer" alt boyutlarında, okuma motivasyonu puanlarının da artacağı söylenebilir. Öte taraftan, Türkçe öğretmeni adaylarının eleştirel okuma öz yeterlik algı ölçeğinin "Değerlendirme" alt boyutu ile okuma motivasyonu ölçeğinin "Tanınma” alt boyutundan almış oldukları puanlar arasında anlamlı bir ilişki olmadığı tespit edilmiştir.

- Türkçe öğretmeni adaylarının, eleştirel okuma öz yeterlik algı ölçeğinin "Araştırma / İnceleme" alt boyutunda almış oldukları puanlar ile okuma motivasyonu ölçeğinin "Benlik" ve "Yeterlilik" alt boyutları arasında pozitif yönlü orta düzeyde bir ilişki; "Diğer" alt boyutu arasında ise, pozitif yönde zayıf düzeyde bir ilişki olduğu görülmüştür. Buna göre; Türkçe öğretmeni adaylarının “Araştırma / İnceleme” alt boyutunda, eleştirel okuma öz yeterlik algı puanlarının artması durumunda "Benlik", "Yeterlilik" ve "Diğer" alt boyutlarında, okuma motivasyonu puanlarının da artacağı söylenebilir. Öte taraftan, Türkçe öğretmeni adaylarının eleştirel okuma öz yeterlik algı ölçeğinin "Araştırma / İnceleme” alt boyutu ile okuma motivasyonu ölçeğinin "Tanınma” alt boyutundan almış oldukları puanlar arasında anlamlı bir ilişki olmadığı tespit edilmiştir.

- Türkçe öğretmeni adaylarının, eleştirel okuma öz yeterlik algı ölçeğinin "Görsel” alt boyutunda almış oldukları puanlar ile okuma motivasyonu ölçeğinin "Benlik" ve "Yeterlilik" alt boyutları arasında pozitif yönlü zayıf düzeyde bir ilișki; "Diğer" alt boyutu arasında ise, pozitif yönde çok zayıf düzeyde bir ilişki olduğu görülmüştür. Buna göre; Türkçe öğretmeni adaylarının "Görsel" alt boyutunda, eleştirel okuma öz yeterlik algı puanlarının artması durumunda "Benlik", "Yeterlilik" ve "Diğer" alt boyutlarında, okuma motivasyonu puanlarının da artacağı söylenebilir. Öte taraftan, Türkçe öğretmeni adaylarının eleştirel okuma öz yeterlik algı ölçeğinin "Görsel" alt boyutu ile okuma motivasyonu ölçeğinin "Tanınma" alt boyutundan almış oldukları puanlar arasında anlamlı bir ilişki olmadığı tespit edilmiştir.

- $\quad$ Son olarak Türkçe öğretmeni adaylarının eleştirel okuma öz yeterlik algı ve okuma motivasyonu ölçeklerinden almış oldukları toplam puanlar üzerinden yapılan korelasyon analizi neticesinde, eleştirel okuma öz yeterlik algıları ile okuma motivasyonları arasında pozitif yönde ve orta düzeyde bir ilişki olduğu görülmüştür. Buna göre; Türkçe öğretmeni adaylarının eleştirel okuma öz yeterlik algı puanlarının artması durumunda okuma motivasyonu puanlarının da artacağı söylenebilir. Literatür incelendiğinde, Epçaçan (2012), ortaokul öğrencilerinin eleştirel okuma becerileri ile okuma tutumları arasındaki ilişkiyi araştırdığı çalışmasında, ortaokul öğrencilerinin eleştirel okuma becerileri ile okuma tutumları arasında doğrusal ve orta düzeyde bir ilişki olduğunu tespit etmiş ve bu bulgudan hareketle eleştirel okuma becerisi arttıkça kişilerin okumaya dair tutum ve algılarının da olumlu yönde geliştiğini ifade etmiştir.

Türkçe öğretmeni adaylarının eleştirel okuma öz yeterlik algıları ile okuma motivasyonları arasındaki ilişkiyi tespit etmeyi amaçlayan bu çalışmadan elde edilen sonuçlar doğrultusunda, aşağıdaki önerilere yer verilmiştir:

- $\quad$ Elde edilen sonuçlar, 4. sınıf öğrencilerinin okumaya yönelik motivasyonlarının bazı alt boyutlarda, diğer sınıf öğrencilerine göre anlamlı bir şekilde azaldığını göstermektedir. Kısa bir süre sonra mesleğe atılacak olan son sınıf öğrencilerinin okumaya yönelik olumlu duygularını ve davranışlarını geliştirecek tedbirler almak ve onlarda okumaya karşı olumsuz hisler oluşturacak etkenleri ortadan kaldırmak; hem bu öğrencilerin kendilerini yeterli hissetmelerini sağlayarak mesleki doyuma ulaşmalarına hem de kendi öğrencilerine çok daha faydalı olmalarına katkı sağlayacaktır.

- Kendilerine ait kitaplıkları bulunan öğretmen adaylarının okumaya yönelik olumlu duygular ve davranışlar oluşturma noktasında daha yetkin olduklarını hem bu çalışmanın hem de literatürdeki birçok çalışmanın sonuçlarında görmek mümkündür. Bu nedenle özellikle Türkçe öğretmeni olacak kişilerin, sürekli kitapla iç içe olmaları ve kendilerine ait bir kitaplık oluşturmaları önemli görülmektedir.

- Okunan kitap sayısının ya da okumaya ayrılan sürenin artmasının okumaya yönelik motivasyonun ve eleştirel okuma öz yeterlik algısının da artmasına katkı sağladığı görülmüştür. Bu nedenle öğretmen adayları, özellikle de Türkçe öğretmeni adayları, kitap okumaya daha çok zaman ayırmaları ve kendilerinde okuma alışkanlı̆̆ı oluşturarak okumayı bir ihtiyaç hâline getirmelidirler. 
- Eğitim fakülteleri, öğrencilerini daha çok kitapla buluşturabilmek adına kütüphanelerini güncellemeli ve içeriğini genişletmelidir.

- Üniversitelerde okumaya ve kitaba yönelik etkinlikler düzenlenmeli ve öğrencileri okumaya teşvik edici uygulamalar hayata geçirilmelidir.

- Türkçe öğretmenliği bölümlerinde okuma ile ilgili verilen dersler, öğrencilerde okuma sevgisi oluşturacak şekilde işlenmelidir. Böylelikle öğrencilerin okumaya yönelik olumlu duyguları ve davranışları da gelişecektir.

- Başta Türkçe öğretmenliği bölümlerinde olmak üzere, tüm öğretmenlik bölümlerinde eleştirel okuma gibi üst düzey düşünme becerilerini geliştirmeye yönelik derslerin yer alması, öğretmen adaylarının mesleki ve kişisel gelişimleri bakımından önemli görülmektedir.

- Türkçe öğretmeni adaylarının, meslek hayatları boyunca karşılaşacakları kendi öğrencilerinde de eleştirel okuma becerisi kazandırabilmek için gerekli yöntem ve teknikleri kullanmayı iyice öğrenmeleri gerekmektedir. Bu nedenle bölümdeki derslerin bu bağlamda yeniden düzenlenmesi gerekmektedir.

- Literatür incelendiğinde, Türkçe öğretmeni adaylarının eleştirel okuma öz yeterlik algıları ile okuma motivasyonları arasındaki ilişkiyi araştıran çalışmaların yetersizliği dikkat çekmektedir. Bu nedenle böyle çalışmaların farklı örneklem grupları ve araştırma yöntemleri ile yapılması ve elde edilen sonuçların karşılaştırılması alanyazına katkı sağlayacaktır.

\section{Kaynakça}

Altunçekiç, A.; Yaman, S. ve Koray, Ö. (2005). Öğretmen adaylarının özyeterlik inanç düzeyleri ve problem çözme becerileri üzerine bir araştırma (Kastamonu ili örneği). Kastamonu Ĕ̆itim Dergisi, 13 (1), 93-102.

Alyılmaz, C. (2010). Türkçe öğretiminin sorunları. Turkish Studies, 5/3, 728-749.

Aşılıoğlu, B. ve Yaman, F. (2017). Öğretmen adaylarının eleştirel okumaya yönelik özyeterlik algıları. Elektronik Eğitim Bilimleri Dergisi, 6/12, 171-179.

Aybek, B. ve Aslan, S. (2015). Öğretmen adaylarının eleştirel okuma özyeterlik algılarının çeşitli değişkenler açısından incelenmesi. Uluslararası Türkçe Edebiyat Kültür Eğitim Dergisi, 4/4, 1672-1683.

Baker, L. (2003). The role of parents in motivating struggling readers. Reading \& Writing Quarterly: Overcoming Learning Difficulties, 19(1), 87-106.

Bandura, A. (1997). Self-efficacy: The Exercise of Control. New York: W.H. Freeman and Company.

Bıkmaz, F. H. (2002). Fen öğretiminde özyeterlik inancı ölçeği. Eğitim Bilimleri ve Uygulama, 1, (2). 197-210.

Bozkurt, M. ve Memiş, A.(2013). Beşinci sınıf öğrencilerinin üstbilișsel okuduğunu anlama farkındalı̆̆ı ve okuma motivasyonları ile okuma düzeyleri arasındaki ilişki. Ahi Evran Üniversitesi Kırşehir Eğitim Fakültesi Dergisi, 14(3), 47-160.

Büyüköztürk, Ş.; Çakmak, E. K.; Akgün, Ö. E.; Karadeniz, Ş. ve Demirel, F. (2011). Bilimsel araştırma yöntemleri. Ankara: Pegem Akademi Yayınları.

Eccles, J. S.; Wigfield, A. ve Schiefele, U. (1998). Motivation to succeed. In N. Eisenberg (Ed.), Handbook of child psychology (Vol. IV, 5th ed., pp. 1017-1095). New York: John Wiley.

Epçaçan, C. (2012). Ortaokul öğrencilerinin eleştirel okuma becerileri ile okumaya ilişkin tutumları arasındaki ilişki. Turkish Studies - International Periodical For The Languages, Literature and History of Turkish or Turkic, 7/4, 1711-1726.

Guthrie, J. T. (2004). Classroom contexts for engaged reading: An overview. In J. T. Guthrie, A. Wigfield and K. C. Perencevich (Eds). Motivating reading comprehension. Concept-Oriented Reading Instruction (pp. 1- 24). NJ: Lawrence Erlbaum Associates. 
An analysis of the correlation between critical reading self-sufficiency perceptions and reading motivations of Turkish teacher candidates / N. Şahin (p. 214-233)

Guthrie, J. T. ve Wigfield, A. (2000). Engagement and motivation in reading. In M. L. Kamil, P. B. Mosenthal, P. D. Pearson, ve R. Barr (Eds.), Handbook of reading research (3rd ed., pp. 403 422). New York: Longman.

Güngör, A. (2005). Altıncı yedinci ve sekizinci sınıf öğrencilerinin okuduğunu anlama stratejilerini kullanma düzeyi. Hacettepe Üniversitesi Eğitim Fakültesi Dergisi, 28, 101- 108.

Hair, J. F.; Black, W. C.; Babin, B. J.; Anderson, R. E. ve Tatham, R. L. (2013). Multivariate Data Analysis. Pearson Education Limited.

Işık, İ. (2001). Öz yeterlik inancı: yönetici rolleri açısından bir inceleme. Yayınlanmamış Doktora Tezi. Marmara Üniversitesi, İşletme Anabilim Dalı. İstanbul.

Karabay, A. (2013). Eleştirel okuma öz yeterlik algı ölçeğinin geliştirilmesi. Turkish Studies International Periodical For The Languages, Literature and History of Turkish or Turkic, 8/13, 1107-1122.

Karasar, N. (2008). Bilimsel araştırma yöntemi. Ankara: Nobel Yayıncılık.

Katrancı, M. (2015). İlkokul dördüncü sınıf öğrencilerinin kitap okuma motivasyonlarının incelenmesi. Ana Dili Eğitimi Dergisi, 3(2), 49-62.

Kurbanoğlu, S. S. (2004). Öz-yeterlik inancı ve bilgi profesyonelleri için önemi. Bilgi Dünyası, 5 (2), 137-152.

Kurnaz, H. ve Yıldız, N. (2015). Ortaokul öğrencilerinin okuma motivasyonlarının çeşitli değişkenlere göre değerlendirilmesi. Türkiye Sosyal Araştırmalar (TSA) Dergisi. 19/3, 53-70.

Kuşdemir, Y. (2014). Doğrudan öğretim modeli’nin ilkokul dördüncü sımı öğrencilerinin okuduğunu anlama becerilerine etkisi. Yayımlanmamış Doktora Tezi, Gazi Üniversitesi, Ankara.

Mcmillan, J. H. ve Schumacher, S. (2010). Research in education: evidence - based inquiry, (7 th Edition). London: Pearson.

Özdemir, S. (2017). Ortaokul öğrencilerinin eleştirel okuma özyeterlikleri. Mehmet Akif Ersoy Üniversitesi Eğitim Bilimleri Enstitüsü Dergisi, 5/7, 41-55.

Özensoy, A.U. (2012). Eleştirel okumaya göre düzenlenmiş Sosyal Bilgiler dersiyle ilgili öğrencilerin görüşleri. Ondokuz Mayıs Üniversitesi Eğitim Fakültesi Dergisi, 31(1), 187 - 202.

Öztürk, E. ve İleri Aydemir, Z. (2013). Başlangıç düzeyi okuyucularının okuma motivasyonlarının, günlük kitap okuma süreleri ve ailenin okuma durumuna göre değerlendirilmesi. Kastamonu Ĕ̆itim Dergisi, 21(3), 1105-1116.

Saracaloğlu, A. S.; Yenice, N.; Karasakaloğlu, N. ve Gencel, İ. E. (2008). Türkçe ve fen bilgisi öğretmenlerinin öğrenme stilleri, ögrrenme stratejileri ve duyuşsal özellikleri ile tercih edilen ögrretme strateji, yöntem ve teknikleri arasındaki ilișki. Yayımlanmamıș Araștırma Raporu, A.D.Ü. BAP Saymanlığı, Aydın.

Schutte, N. S. and Malouff, J. M. (2007). Dimensions of reading motivation: Development of an adult reading motivation scale. Reading Psychology: An International Quarterly, 28, 469 - 489.

Selçuk, Z. (2007). Eğitim psikolojisi. Ankara: Nobel Yayın Dağıtım.

Senemoğlu, N. (2011). Gelişim, öğrenme ve öğretim kavramdan uygulamaya. Ankara: Pegem Akademi.

Slavin, R. E. (2013). Eğitim psikolojisi. (10. Baskı) (Çev. Edt. G. Yüksel). Ankara: Nobel Yayın Dağıtım.

Topçuoğlu Ünal, F. ve Sever, A. (2013). Türkçe öğretmeni adaylarının eleştirel okumaya yönelik özyeterlik algıları. Dil ve Edebiyat Eğitimi Dergisi, 2(6), 33-42.

Wigfield, A. ve Guthrie, J. T. (1997). Relations of children's motivation for reading to the amount and breadth of their reading. Journal of Educational Psychology, 89, 420-432. 
Wigfield, A.; Eccles, J. S. ve Rodriguez, D. (1998). The development of children's motivation in school contexts. In. A. Iran-Nejad \& P. D. Pearson (Eds.), Review of research in education (Vol. 23, ss.73118). Washington, DC: American Educational Research Association.

Yıldız, M. (2010). İlköğretim 5. sını öğrencilerinin okuduğunu anlama, okuma motivasyonu ve okuma alışkanlıkları arasındaki ilişki. Yayımlanmamış Doktora Tezi. Gazi Üniversitesi, Eğitim Bilimleri Enstitüsü, Ankara.

Yıldız, M. (2013). İlköğretim 3, 4 ve 5. sınıf öğrencilerinin okuma motivasyonlarının incelenmesi. Eğitim ve Bilim, 38(168), 260-271.

Yıldız, M.; Yıldırım, K.; Ateş, S. ve Çetinkaya, Ç. (2013). Yetişkin okuma motivasyonu ölçeğinin Türkçe uyarlaması. Elektronik Sosyal Bilimler Dergisi, 12/44, 348-359. 